\title{
Information Literacy As Fetishized Theoretical Category - An Example of Pro-ana Youth Blogs
}

\section{KEYWORDS}

sociology of education, information literacy, media education, sociology of the Internet, pro-ana, anorexia nervosa

\begin{abstract}
Scientific reflections on information literacy have emphasized that young people must develop information competences related to using the Internet. Among various approaches, in the generic approach, catalogues of competences are constructed and treated as lists of desired behaviours and skills. The article aims to criticize this approach and its characteristic fetishization of theoretical categories; because of fetishization, these catalogues of competences fail to reflect social reality. The article presents the practices of female bloggers of the pro-ana movement: young girls who consider anorexia not a disease but a lifestyle. Using the method of content analysis, the author analysed 561 blog entries on 15 blogs and compared the collected data with a model catalogue of competencies created based on the literature. Perceived from the perspective of the generic approach, female pro-ana bloggers may be considered informationliterate. This implies that this approach is deficient as the pro-ana movement negatively impacts both healthy and ill girls. The analysis indicates that proponents of the generic standpoint should distinguish the so called competent negative uses.
\end{abstract}

\section{Introduction}

Nowadays, information competences, i.e. information literacy, have become the subject matter of extensive studies, carried out usually in reference to new information technologies, mainly to the Internet. Being competent in the field of information technology, i.e. information literate, is connected with the adequate ability to efficiently search for, store, control, produce or communicate information using the Internet. ${ }^{1}$ The information literacy discussed here is also referred to as informa-

\footnotetext{
${ }^{1}$ S. Talja, A. Lloyd, Integrating theories of learning, literacies and information practices, [in:] Practising Information Literacy: Bringing Theories of Learning, Practice and Information Literacy Together, A. Lloyd, S. Talja (eds), Wagga Wagga 2010, Centre for Information Studies, pp. VIII-XX; K. Tuominen, R. Savolainen, S. Talja, Information literacy as sociotechnical practice, "Library Quarterly," 2005, No. 75, pp. 329-345.
} 
tion technology (IT) literacy, digital literacy or network literacy. Different discourses approach the issue of information competence in a variety of ways, each time emphasizing the need to acquire or enhance them.

Primarily young people are to be the subject of various activities, though this age category can be understood very broadly: professional literature published in this field draws attention to the need for appropriate education of pre-schoolers as well as students at different educational stages (at primary schools, junior high schools, senior high schools or at colleges). ${ }^{2}$ These competences should be instilled in various manners: formally, i.e. as part school or college curriculum, but also in the course of so-called informal education, i.e. with peers or adults in the course of everyday life.

The aforementioned discourses on informative competences were very thoroughly discussed by Mandy Lupton and Christine Bruce in their article titled Windows on information literacy worlds. ${ }^{3}$ They identified three approaches: generic, situated, and transformative. The last one of the three constitutes a critical approach focusing on the emancipation of individuals and groups. Being literate is described here as tantamount to being able to undermine the status quo and effectively initiate social change. ${ }^{4}$ As such, however, this approach remains beyond the scope of my present interest, contrary to the situational approach, which links competences with social practices in the sense that competences should be "situated" within these practices. ${ }^{5}$ Competences vary depending on the context and are shaped by the given cultural and social conditions; it is therefore necessary to speak not only of a single information literacy, but of information literacies. We are dealing with a sociocultural movement which deals with information competence in the following manner:

In this perspective, literacy is contextual, authentic, collaborative and participatory. Literacy involves individuals and groups making decisions, making meaning and solving personal, work, family and community problems. It is subjective, as what constitutes literacy practices will vary with the context and be different for each person and social group. ${ }^{6}$

2 S. Livingstone, Children's use of the internet: Reflections on the emerging research Agenda, "New Media \& Society," 2003, No. 5(2), pp. 147-166; S. Livingstone, “Children and the Internet," Polity Press, Cambridge-Malden 2009.

${ }^{3}$ M. Lupton, C. Bruce, Windows on information literacy worlds: Generic, situated and transformative perspectives, [in:] Practising Information Literacy: Bringing Theories of Learning, Practice and Information Literacy Together, A. Lloyd, S. Talja (eds), Wagga Wagga 2010, Centre for Information Studies, pp. 3-28.

${ }^{4}$ Cf. B. Endres, A critical read on critical literacy: From critique to dialogue as an ideal for literacy education, "Educational Theory," 2001, No. 51(4), pp. 401-413.

${ }^{5}$ Cf. A. Lloyd, Lessons from the workplace: Understanding information literacy as practice, [in:] Practising Information Literacy: Bringing Theories of Learning, Practice and Information Literacy Together, A. Lloyd, S. Talja (eds), Wagga Wagga 2010, Centre for Information Studies, pp. 29-50.

${ }^{6}$ M. Lupton, C. Bruce, op. cit., pp. 7-8. 
Emphasizing the sociocultural nature of information literacy is significant from the perspective of the proposed educational measures relating to the formal education system. ${ }^{7}$ Students should not be treated like robots programmed to function in accordance with one definition of competence accepted by the educator. Rather, the educational process should be adapted to each individual student, taking into account his/her everyday life and the sociocultural context in which he/she functions. The proponents of the situational approach also point out that the acquisition of skills has a communal dimension; the point is that we learn (and generate new knowledge) as members of diverse groups. This is particularly evident in the case of so-called communities of practice, defined as groups of people sharing common interests and objectives. ${ }^{8}$ While implementing the objectives of a group, its members employ similar practices, use similar tools or the same language. Communities of practice arise when people engage in similar activities, share concerns or have the same understanding of specific problems. ${ }^{9}$

The contextual nature of information literacy seems to have been overlooked by scholars representing the generic approach about which Lupton and Bruce wrote the following:

The generic perspective portrays literacy as 'functional' or 'basic'. In this perspective, literacy is regarded as a discrete set of skills to be learned by individuals (...). In the generic perspective, literacy is neutral, objective, text-based, apolitical, reproductive, standardized and universal. ${ }^{10}$

Competences are treated here in terms of a list of desirable behaviours and skills and with complete disregard for human practices. Acquisition and various uses of information are to be independent of the context or everyday life of different social groups.

The generic approach manifests itself in constructing diverse catalogues of competences. They are usually developed as part of a media education project or are part of a larger text. They create an inventory of what young people need to know, what skills they should have and be aware of if they want to be Internet-literate. ${ }^{11}$ There are so many catalogues that it would be very difficult to list

7 Ibidem; L. Lipponen, Information literacy as situated and distributed activity, [in:] Practising Information Literacy: Bringing Theories of Learning, Practice and Information Literacy Together, A. Lloyd, S. Talja (eds), Wagga Wagga 2010, Centre for Information Studies, pp. 51-64.

${ }^{8}$ Cf. E. Wenger, "Communities of Practice: Learning, Meaning, and Identity (Learning in Doing: Social, Cognitive and Computational Perspectives)," Cambridge University Press, Cambridge 2000.

${ }^{9}$ Cf. J.S. Brown, P. Duguid, Knowledge and organization: A social practice perspective "Organization Science," 2001, N. 12 (2), pp. 198-213; P. Harris, Communities as necessity in information literacy development: Challenging the standards, "Journal of Academic Librarianship", 2008, No. 34, pp. 248-255.

${ }_{10}$ M. Lupton, C. Bruce, op. cit., p. 7.

${ }^{11}$ Cf. E.A. Rozkosz, P. Siuda, G.D. Stunża, A.J. Dąbrowska, M. Klimowicz, E. Kulczycki, D. Muszyński, R. Piotrowska, M. Sieńko, K. Stachura, Information and Media Literacy of Polish Children According to the 
them all. Researchers are usually commissioned to create them by scientific institutions, third sector organisations or government agencies. When it comes to English-language catalogues, the ones worth mentioning have been published by the following institutions: the American Association of School Librarians, ${ }^{12}$ the American Association of School Librarians and Association for Educational Communications and Technology, ${ }^{13}$ the Council of Australian University Librarians. ${ }^{14}$ or the International Federation of Library Associations and Institutions. ${ }^{15}$

Although catalogues cannot be classified into one category, they offer quite similar sets of competences (I shall mention this further). Some catalogues emphasize the context of competences, but this fact fails to convince the proponents of the situated approach. According to them, the very nature of the catalogue - understood as a set of certain skills mentioned in turn - provokes the misconception of information competences. The interpretation of catalogues and their general reception in the sphere of formal education are always generic, even if catalogues are oriented towards the socio-cultural context. ${ }^{16}$ Catalogues necessitate a way of thinking that is neither seen nor discussed in this context. The objective is simply to present an ideal "skilful" individual who is to become competent by following a series of steps leading to the acquisition of further skills. ${ }^{17}$

Results of "Children of the Net" and "Children of the Net 2.0" Studies, [in:] Information Literacy: Lifelong Learning and Digital Citizenship in the 21st Century, S. Kurbanoğlu, S. Špiranec, D. Mizrachi, R. Catts (red.), Cham 2014, Springer, pp. 263-273.

12 AASL, Standards for the 21st-Century Learner, 2007, http://www.ala.org/aasl/standards-guidelines/ learning-standards (accessed on: 12.03.2016).

${ }_{13}$ AASL, AECT, Information Literacy Standards for Student Learning: Standards and Indicators, 1998, http://www.ilipg.org/sites/ilipg.org/files/bo/InformationLiteracyStandards_final.pdf (accessed on: 12.03.2016).

${ }^{14}$ ANZIIL, Australian and New Zealand Information Literacy Framework: principles, standards and practice, 2004, http://www.caul.edu.au/caul-programs/information-literacy/publications (accessed on: 12.03.2016).

${ }^{15}$ IFLA, Beacons of the Information Society: The Alexandria Proclamation on Information Literacy and Lifelong Learning, 2005, http://www.ifla.org/publications/beacons-of-the-information-society-the-alexandria-proclamation-on-information-literacy (accessed on: 12.03.2016); IFLA, The Moscow Declaration on Media and Information Literacy, 2012, http://www.ifla.org/publications/moscow-declaration-on-media-and-information-literacy (accessed on: 12.03.2016).

${ }^{16}$ Cf. S. Edwards, C. Bruce, The assignment that triggered change: Assessment and the relational model for generic capabilities, "Assessment and Evaluation in Higher Education", 2004, No. 29 (2), pp. 141-157; M. Lupton, "The learning connection: Information literacy and the student experience," Auslib Press, Adelaide 2004; J. Purdue, Stories, not information: Transforming information literacy, "Portal: Libraries and the Academy," 2003, No. 3(4), pp. 653-662.

${ }_{17}$ M. Eisenberg, R. Berkowitz, "Information problem-solving: The Big Six approach to library \& information skills instruction," Ablex, Norwood 1990. 
The present article advocates the situated approach. I join the group who criticize the generic approach as forcing us to create more catalogues. My claim is that catalogues manifest the fetishization of theoretical categories, which is a significant methodological oversight. It consists in a complete separation of both research or education processes from social reality.

The aim of the article is to criticize the generic trend and the fetishization through the prism of particular practices of young people. I shall focus on the phenomenon of pro-ana sites online, i.e. groups of girls who believe that anorexia is a specific lifestyle. For the purposes of my argument, it does not matter whether the pro-ana are described as a social movement or whether another concept - for example, a subculture or sect - is "attached" to it. ${ }^{18}$ It is important that we are dealing with young girls - usually between the ages of 16 and 25 - who are either already suffering from anorexia or have significant predispositions to become ill. For them, the Internet is a space where they can divulge the truth about their anorexia or anorectic tendencies. One can do this, both by setting up web pages or blogs, but also using social network profiles (for example Facebook) - for the purposes of the article, I shall focus on blogs. The literature on the subject still lacks any indication of the drawbacks of a generic approach by giving specific exemplifications regarding young people. ${ }^{19}$

I am critiquing fetishization by proving that persons from the pro-ana movement are information literate, if we view them with regard to catalogues characteristic for a generic approach. As I will show in the last part of the article, pro-ana membership unfavourably affects health and psychological or social development of girls. Proving that they are literate, if we consider them having in mind competence catalogues, will constitute unmistakable evidence of inappropriateness of a generic approach. Ironically, I am employing the methods most frequently adopted by its representatives to critique this approach. This is them who are in favour of the studies which check to what extent literacy of members of a studied group correspond to a certain a priori accepted pattern.

The example of pro-ana shown by me reveals rarely mentioned and commented weakness of a generic approach. I mean assuming beforehand that young people, who learnt to use the web due to various educational decisions, will always use the acquired abilities for their advantage. It goes unnoticed that it does not

\footnotetext{
${ }^{18}$ Cf. M. Klichowski, Pro-ana - internetowa sekta nastolatek, [in:] Świat Digital Natives. Młodzież w poszukiwaniu siebie i innych, H. Krauze-Sikroska, M. Klichowski (eds), Poznań 2013, Wydawnictwo Naukowe UAM, pp. 157-172.

${ }^{19}$ Cf. A. Lloyd, op. cit., pp. 29-50.
} 
necessarily have to be like that, since people use the acquired competences in their everyday activities, which not always have a positive impact on them.

Catalogues, characteristic for a generic approach, are strongly biased. As a matter of fact, a category of "wise" or "thoughtful" use of information for the benefit of the others and one's own has occurred in some of them, but even if this happens, the category is not discussed more broadly. Catalogues usually conclude that a person is competent when he/she knows or can do specific things. ${ }^{20}$

\section{Methods}

As I have already mentioned, I critique fetishization by proving that pro-ana girls are information literate from the perspective of competence catalogues typical for a generic approach. That is why a brief synthetizing look at the content of these catalogues is necessary. Earlier, I observed that there are numerous of them and listing them all is not the aim of this paper. Some catalogues are more precise, others less; some use a bigger number of exemplary competences, others a smaller one. In various lists, abilities are differently arranged and named, however, in vast majorities of catalogues, actually, these are listed which I am going to describe below. ${ }^{21}$

They are to be key ones for a young person growing up in the internet world. Generally speaking, it can be said that here presented synthesizing overview is a specific mirror of many different catalogues.

First of all, getting information efficiently and effectively, which for example means that when you want to find a specific piece of information in the web you should adapt the search tool appropriate for the type of the searched content. Everybody should know that it is best to look for educational aids in services such as Wikipedia, and film descriptions can be found, for instance, in IMDb. Secondly, it is good to acquire various abilities, for example, an ability to enter appropriate key words (giving the best search results) in the internet search engines. Another required competence is to critically evaluate information, among other things, realizing that internet sources can be wrong. An entry in Wikipedia can contain

\footnotetext{
${ }^{20}$ L. Lipponen, op. cit., p. 55.

${ }^{21}$ Cf. P. Siuda, G.D. Stunża (red.), "Dzieci Sieci - kompetencje komunikacyjne najmłodszych: Raport z badań" ("Children of the Network - Communication Competences of the Youngest Children: Research Report”), Instytut Kultury Miejskiej, Gdańsk 2012; P. Siuda, G.D. Stunża, A.J. Dąbrowska, M. Klimowicz, E. Kulczycki, R. Piotrowska. E. Rozkosz, M. Sieńko, K. Stachura, "Dzieci Sieci 2.0. Kompetencje komunikacyjne młodych" ("Children of the Network 2.0 Communication Skills of Young People"), Instytut Kultury Miejskiej, Gdańsk 2013.
} 
many errors which should be spotted by every person efficiently using the internet, or at least the person should understand the need to verify the found information, or to obtain additional information from other sources. Thirdly, it is important to be able to create, process and present messages, and know legal aspects of their preparation. It is very good when a young person posts his/her own photographs or films online, and can remix or process online found materials in different way, and uses them for his/her creative activities, and additionally, he/she knows how to do it not to violate the copyright. Fourthly, a safe use of the internet is crucial, thus not disclosing the passwords, avoiding cyberbullying, which translates into being provoked by others, not responding to messages from suspicious (strange) people or creating his/her own image to show the creator in a favourable light. The latter one refers to, for example, not posting on various social media sites photographs, films or other materials which can embarrass a given individual, for instance those which can indicate that somebody is intoxicated. Fifthly, young people should be sociable on the web, which means that they should join various groups. If you have a Facebook profile, it is worth being active in such a manner as to meet people who could offer some support, for example, offer information, or ask other users for advice in various matters.

In order to check whether girls from the pro-ana movement can be considered literate - if the above-described synthesizing model of catalogues is employed I decided to study a phenomenon of pro-ana with the use of the content analysis, i.e. I investigated various pro-ana blogs. It is worth noting that online research methods seem best as far as the analysis of the pro-ana is concerned, since it is only online phenomenon, the web is a meeting place of these girls. Due to the necessity to stay anonymous, they do not meet offline, and they do not reveal any data which could help to identify them (I am writing more about it later in my paper).

Unusual "secretiveness" of the pro-ana representatives makes it extremely difficult to carry out netnographic research in the form described by Robert V. Kozinets, ${ }^{22}$ i.e. involving the observation of what members of a given society are doing online, and simultaneously interacting with them. That is why I limited myself only to the "pure" content analysis which I used to understand meanings, motifs and patterns manifesting themselves in a studied society. Certainly, referring to the literature on pro-ana was helpful in discovering these meanings.

I analysed 15 blogs, however, I do not give their names or web addresses. Revealing them would be ethically doubtful. As I have already mentioned, the users

${ }^{22}$ R.V. Kozinets, “Netnography: Doing Ethnographic Research Online," SAGE Publications, London-Thousand Oaks-New Delhi 2010. 
of pro-ana sites are extremely careful not to give any personal data that would help to identify the girls. Although pro-ana blogs function in the "public sphere," which means that everybody has access to them, it can be suspected that girls treat the blogs as a private space. As it was indicated by many methodologists of online research, I encountered there a complicated nature of relations between the public sphere and the private one. ${ }^{23}$ In the cyberspace, it is frequently hard to tell whether we deal with the former or the latter one. If we look at opened nature of a given place, we should conclude that it is a public sphere. However, if we take into consideration that people reveal a lot of private and frequently embarrassing and intimate information within a community, a group should be perceived as belonging to a private sphere. The criterion of common access ceased to be a reliable indicator of a public sphere. It is a mistake to approach texts people post on the internet in the same way interviews in newspapers and TV or radio programmes are treated. Though, frequently the access to the internet content is not restricted, people can be unaware of this and think that information reaches only those who will respect and understand their situation, problems, etc.

I was guided in my evaluation by advice phrased by Storm A. King. ${ }^{24}$ The researcher suggested that the degree of privacy breach online should be evaluated by considering their emotional state and their feeling of privacy, as well as by taking a critical look at your own studies. Certainly, the difference between investigations on sport, music or film and these related to people experiencing a life crisis seems significant.

Although I used a content analysis, i.e. nonreactive method based on the interactions between social actors, I decided not to reveal here the studied blogs and not to quote entries. I did it having in mind extremely sensitive nature of what the pro-ana users post on blogs, and girls' care for their anonymity and privacy. Simultaneously, common access to the studied sites and above-mentioned non-reactivity of the research procedure allowed me to carry out the analysis without necessity to look for the informed consent of the studied.

The chosen blogs do not constitute a representative sample since it is practically impossible to have one when studying various internet sites. The described procedure did not differ from many others of its kind. Non-representativeness is

${ }^{23}$ Cf. D.M. Berry, Internet research: privacy, ethics and alienation: an open source approach, "Internet Research”, 2004, No. 4 (14), pp. 323-332; B.F. Peden, D.P. Flashinski, Virtual Research Ethics: A Content Analysis of Surveys and Experiments Online, [in:] Readings in Virtual Research Ethics. Issues and Controversies, E.A. Buchanan (eds), Hershey-London-Melbourne-Singapore 2004, INFOSCI, pp. 1-26.

${ }^{24}$ S.A. King, Researching Internet Communities: Proposed Ethical Guidelines for the Reporting of Results, “The Information Society”, 1996, No. 12, pp. 119-127. 
a universal weakness of online research, it is indicated as the biggest shortcoming of this research method. ${ }^{25}$ It is not possible to construct the list of pro-ana blogs, which might be used for sampling. There are so many blogs, they are in many different languages, and they also have various "expiry date" - some exist for long time, for example for a few years, others "die out" quite quickly, and what is most important, their list cannot be found anywhere.

I selected blogs using as a guideline the criterion of "popularity" and the degree of bloggers' activity. I understood popularity simply as taking top positions in Google Search after writing such phrases as "pro-ana", "pro-ana butterflies" (I am explaining the meaning of this term later), "pro-ana movement", "pro-ana blog." After entering a given phrase, also websites which were not blogs occurred in a search engine, that is why I scrolled search results downwards, including into the study blogs from further positions. However, I did not only go by the position in the search results. In order to investigate a given blog, it had to be active. I considered a blog active when a blogger wrote at least 3 posts every month over the minimum period of time of six months. Including only active blogs into the study ensured me that I am studying a phenomenon which is "authentic" and "alive." It is worth stressing that I found blogs which were active in various periods of time. The "oldest" one was active since May to October 2008, the "youngest" one, since January to July 2014. Let me point out that though I studied every blog for six months it does not mean that girls did not write more than 3 posts in the following months in the case of some blogs. Even if that happened, I always took into consideration the period of six-month activity, beginning from the moment when at least 3 posts occurred in any month since the blog had been started.

Intentionally, I evaluated up-to-datedness of the studied sites going by the number and frequency of posts. Although blogs contain many other elements, ${ }^{26}$ posts constitute their essence. In posts, bloggers upload their creations in a written or graphic form, or share links to interesting websites, films or graphics found in the internet. I chose entries to be units of analysis; on each of 15 blogs, I studied all posts from the period of 6 months, i.e. 561 entries in total. The blog with the largest

\footnotetext{
${ }^{25}$ J. Blasius, M. Brandt, Representativeness in Online Surveys through Stratified Samples, "Bulletin de Méthodologie Sociologique," 2010, No. 107, pp. 5-21; R.D. Fricker, M. Schonlau, Advantages and Disadvantages of Internet Research Surveys: Evidence from the Literature, "Field Methods," 2002, No. 14 (4), pp. 347-367; J.H. Krantz, R. Dalal, Validity of Web-Based Psychological Research, [in:] Psychological Experiments on the Internet, M.H. Birnbaum (ed.), New York 2000, Academic Press, pp. 35-60; U.D. Reips, Standards for Internet-Based Experimenting, "Experimental Psychology," 2002, No. 49 (4), pp. 243-256.

26 J.W. Rettberg, “Blogging," Polity Press, Cambridge-Malden 2013.
} 
number of entries (within six months) contained 58 of them, whereas the blogger with the lowest number of entries posted 22 of them.

The content present in the analysed entries was manually coded (I did not use any software), while I highlighted the code categories based on the above-presented model synthetic catalogue of competences. It also became a basis for the subdivision of categories into a few sections. I am presenting these sections and separate categories in the next part of my article. It will be shown that I also studied comments to the entries, though the analysis was of a limited scope (I distinguished only 3 coding categories), I studied 1011 comments in total.

\section{Results}

The entries on pro-ana blogs were analysed for the content serving as the evidence that bloggers acquired the abilities presented in the model catalogue. I distinguished many coding categories subdivided into different types, and I checked in how many of the studied entries they occur. I presented the data in Table 1, which can be found in the final section of this part of the article. In the following paragraphs, I am going to analyse and interpret the collected material, though I must add that wherever I wrote about frequency of specific categories, I refer the reader to the mentioned table without pointing it out in the text, and without citing figures.

Girls acquired the ability to efficiently and effectively get information because their blog entries contain very detailed information on anorexia, both, links to newspaper articles and scientific works on anorexia (the former ones in the biggest numbers) can be found on them. However, this does not exhaust the knowledge the users "brag about." The content of entries and references also regard various wonder diets, methods of fighting with overweight, ways to induce vomiting or diarrhoea artificially, or ways to carry on fasting. So, called tips \& tricks, i.e. clues how to deceive the family and friends, or specialists to avoid treatment, are a frequent element of blogs. ${ }^{27}$ The pieces of advice are usually "ornamented" with links to sources, which proves that girls have the ability to find them in the internet.

Naturally, one may wonder whether bloggers critically evaluate the information they obtain. This is not "polemical reception" if we view this problem in the light of terrible health consequences of all described and linked to "treatments"

${ }^{27}$ Cf. M. Barczak, Krótka charakterystyka dzienników internetowych dziewcząt z anoreksją (Internet diaries by girls with anorexia: A brief description), [in:] Opętanie (nie)jedzeniem [(Non)-eating Obsession], B. Ziółkowska (ed.), Warszawa 2009, Scholar, pp. 155-158. 
and tricks. On the other hand, it seems that the information is critically evaluated, since materials which are found and recommended perfectly serve a purpose which anorexic girls want to reach. Critical reception is evident when we compare the entries which differ in terms of radicalness of presented opinions. More extreme girls want to "popularize" anorexia, which means they do not treat it as a disease. Moderate girls work to promote acceptance of eating disorders, namely, they claim that you can function with them normally, and not necessarily you should immediately undergo treatment. It is questioned that the behaviour of sick persons should be replaced by "normal" eating habits, and anorectic rituals should be eradicated. Leaving the content of the postulates aside, it is worth stressing that it is very easy to recognize the follower of which option writes the blog. Messages presented to the visitors are a perfect proof of being an expert on the subject, and belief in rightness of the cause. It can be said that accepting a certain option (the extreme or moderate one) the representatives of pro-ana consciously and polemically read the consumed-elsewhere materials - journalistic, scientific or any other ones (it is worth noting that both attitudes have already been recognized and well described in the literature ${ }^{28}$ ).

Another ability distinguished in a model catalogue is creating and processing information, which translates into uploading texts, photographs, films and other messages on the internet, self-created, or remixed, i.e. employing the content found somewhere in the internet. As long as analysed pro-ana blogs are considered, this type of creativity is omnipresent. It can be seen in personification of the disease, because girls upload letters written to and from anorexia, or poems dedicated to her, as well as they give her a pet name ("Ana", "goddess" or "friend").

So, called thinspirations, i.e. everything that should inspire and motivate for dieting, can be considered a specific treasure chest of amateur-created materials. They can be processed graphics of so called real girls or celebrities, namely actresses, models, and singers. Most frequently, they are collages of a few separate photographs to which a "militant" slogan is added, such as "skinny bitch", "razor sharp", "I only feel beautiful when I'm hungry", etc. (see Illustration 1.) A common feature of the presented persons is their very slim figure, and for collages, photographs of females in the poses which expose protruding hip bones, ribs, knees or collarbones are chosen. Slim stomachs or buttocks of models are shown, and photographs of celebrities are frequently altered so that the famous persons look even thinner than in reality. Certainly, such photographs with captions are to show

${ }^{28}$ Cf. I. Startek, Motyle w sieci. Krótka charakterystyka ruchu pro-Ana, "Curr Probl Psychitry," 2011, No. 12 (3), pp. 322-329. 
that achieving a very low weight is possible. Different function is fulfilled by photo thinspiration where people binging on caloric food or obese ones are presented. It is about creating fear for overweight and discouraging girls from eating, as well as specific punishment for people who could not resist and ate too much.

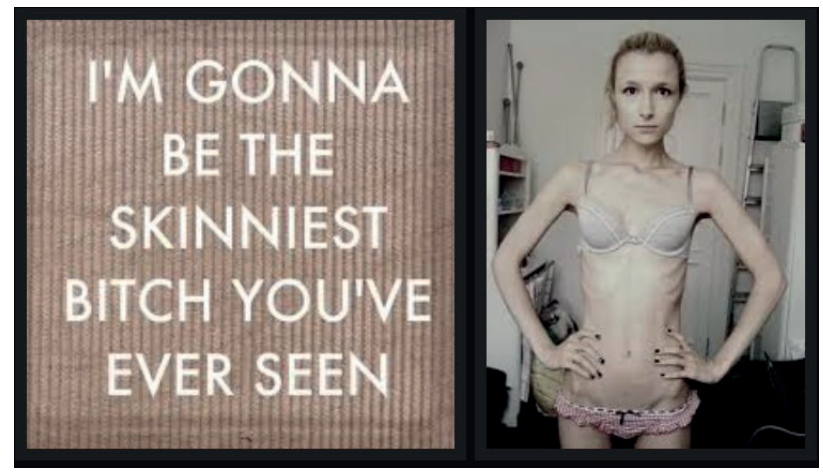

Fig. 1. Photo thinspiration (from a blog which was not analysed)

Source: http://be-skinny-pro-ana.blogspot.com/p/pro-ana-abc.html.

Photographic content is dominant, which doesn't mean that you won't find other type of content on the blogs. It is worth mentioning the so-called vids, i.e. amateur videos showing subsequent shots enhanced with relevant musical background. In the case of pro-ana vids, the photographs are similar to the ones mentioned above. Film thinspirations are also mixed Hollywood images, while the scenes included in the videos feature only thin actresses. Also, musical pieces created by the girls themselves or by professional artists are supposed to "motivate them to work." 29

It should be noted that the authors of pro-ana blogs are very careful in promoting the content that is shocking for an average internet user and they pay extra attention not to disclose their personal data or to include anything that would make it possible to identify them ${ }^{30}$. If they write about their own experience, they make an effort to make the description anonymous and avoid disclosing any details from their own lives, as well as information about other people. If they do publish their photos, they show only those body parts, which induced them to go on a diet. You can say the bloggers are competent as regards protecting their privacy and avoiding posting any compromising material on the internet.

\footnotetext{
29 Ibidem.

${ }^{30}$ Cf. R. Fleming-May, L.E. Miller, "I'm scared to look. But I'm dying to know": Information seeking and sharing on Pro-Ana weblogs, "Proceedings of the American Society for Information Science and Technology," 2010, No. 47 (1), p. 1-9.
} 
What about the next competence, i.e. participation in the internet communities? The literature on the subject strongly emphasizes the fact that pro-ana websites are nothing else than communities that are specific support groups for their members ${ }^{31}$. In claiming this, we refer to the sociologically proven role of the internet as a platform promoting contact, exchanging opinions and sharing experience $^{32}$. The coherence of a community is proven by specific norms and values identified by the members as well as the creation of a specific language or group ethos.

Legitimizing anorectic rites and behaviours as well as collective recognition of pain, emotional restlessness, suffering and struggle that is to be conducive to the ultimate victory - all this is an element of the pro-anal culture. These elements are an embodiment of a subjective experience of being different, which also includes distancing oneself from the dominant opinion on what a healthy human body should be like. The girls refer to themselves as butterflies, which is supposed to be associated with something light, ephemeral and therefore free. A butterfly as a symbol of the movement is also supposed to stand for the transformation that the girls may undergo - from an ugly (fat) caterpillar into a beautiful (thin), ethereal and weightless insect. In order to complete this transformation, the girls are supposed to observe the so called Pro-ana Decalogue, which is often included on the blogs and as such constitutes a set of rules of conduct (see Fig. 2.). What is also important is the proana alphabet (see Fig. 3.), where each letter has an assigned term related to slimming. Various daily, weekly and monthly calorie intake limits are also significant.

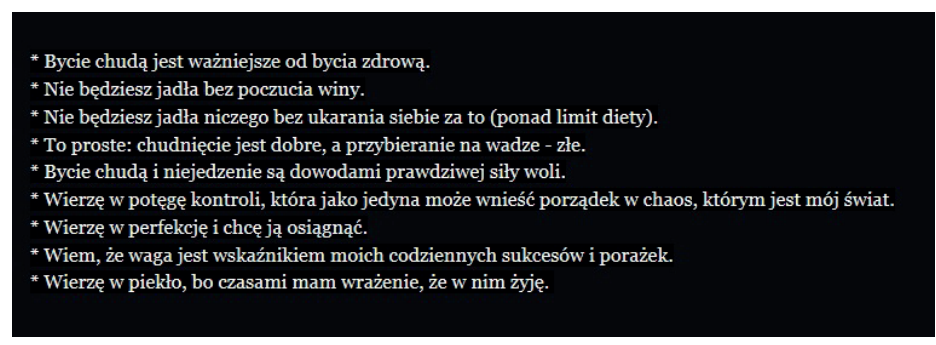

Fig. 2 Pro-ana Decalogue (from a blog that was not subject to analysis)

Source: http://be-skinny-pro-ana.blogspot.com/p/pro-ana-abc.html.

${ }^{31}$ Cf. S. Dyke, Utilising a blended ethnographic approach to explore the online and offline lives of proana community members, "Ethnography and Education", 2013, No. 8(2), pp. 146-161; D. Yeshua-Katz, N. Martins, Communicating Stigma: The Pro-Ana Paradox, "Health Communication," 2013, No. 28 (5), pp. 499-508.

${ }^{32}$ P. Siuda, Społeczności wirtualne. O wspólnotowości w społeczeństwie sieciowym (Virtual Communities. On Community in a Network Society), [in:] Oblicza Internetu, Internet w przestrzeni komunikacyjnej XXI wieku (Faces of the Internet. Internet in the Communication Space of the 21st Century), M. Sokołowski (ed.), Elbląg 2006, Wydawnictwo PWSZ, pp. 179-186. 


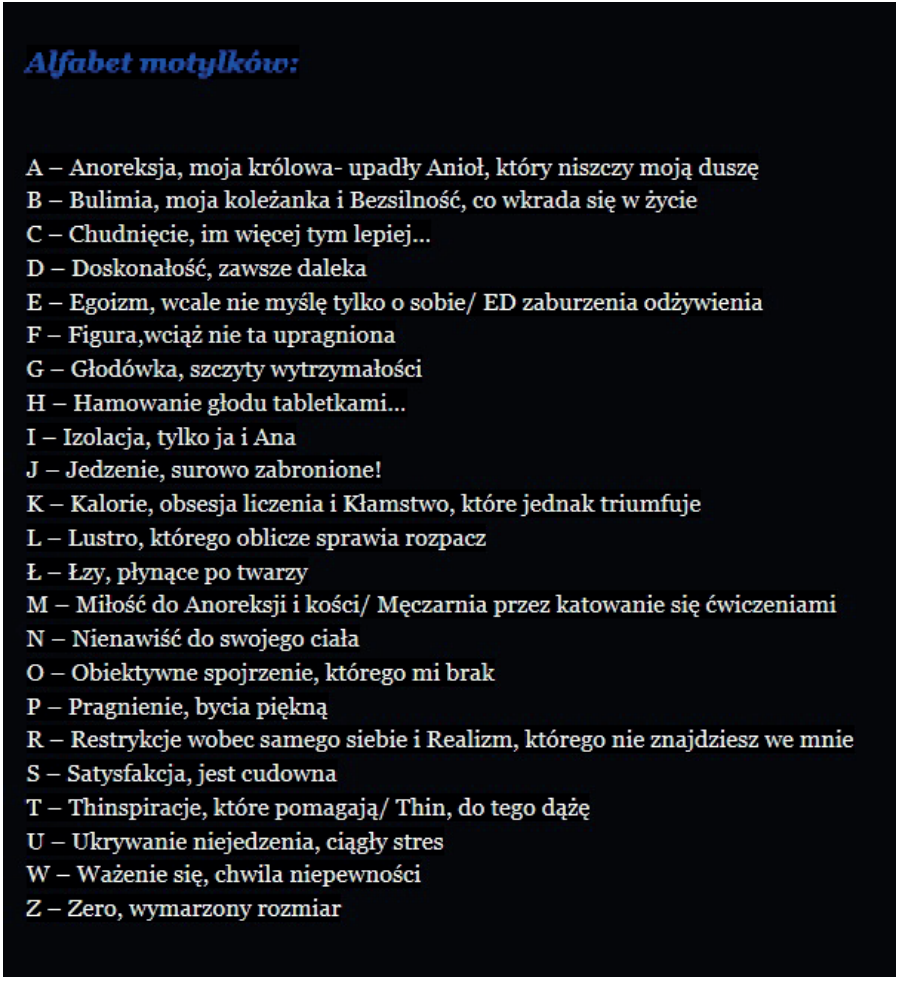

Fig. 3 Pro-ana alphabet (from a blog that was not subject to analysis)

Source: http://be-skinny-pro-ana.blogspot.com/p/pro-ana-abc.html.

As some cultural studies ${ }^{33}$ researchers have shown, pro-ana places for celebrating eating disorders constitute communities where the feeling of belonging is built on the basis of having an anorectic body. By encouraging its members to articulate their opinions, these communities strive to challenge the rules imposed by the common so-called economy of difference. An anorectic body is always stigmatized as different from "normal". Based on culture-imposed classifications, anorectic people are excluded as "different". Such exclusion from the "healthy" society and intolerance to whatever is different is aimed at reconstructing the social and cultural consensus based on the constant emphasis of differences and excluding

${ }^{33}$ K. Dias, The Ana Sanctuary: Women's Pro-Anorexia Narratives in Cyberspace, "Journal of International Women's Studies," 2013, No. 4 (2), pp. 31-45; D. Ferreday, Unspeakable Bodies. Erasure, Embodiment and the Pro-Ana Community, "International Journal of Cultural Studies," 2003, No. 6 (3), pp. 277-295; N.J. Fox, K.J. Ward, A.J. O'Rourke, 'Expert Patients,' Pharmaceuticals and the Medical Model of Disease: The Case of Weight Loss Drugs and the Internet, "Social Science and Medicine," 2005, No. 60 (6), pp. 1299-1309; N.J. Fox, K.J. Ward, A.J. O’Rourke, Pro-Anorexia, Weight Loss Drugs and the Internet: An AntiRecovery Explanatory Model of Anorexia, "Sociology of Health and Illness," 2005, No. 27 (7), pp. 944-971; Ward, op. cit. 
various social groups. Without deliberating whether or not such convictions are right, I would like to point out that such opinions are always doubled with showing the community nature of the pro-ana movement - the websites are shown as places where people with similar views come together and offer each other some sort of support.

When looking from this perspective, pro-ana communities are a sanctuary that guarantees a refuge from the external world, full of threats and wanting to pigeon-hole the girls who observe the pro-ana guidelines and classify them as sick or at a risk of an illness ${ }^{34}$. In these communities, you can win a high position not by observing the commonly recognized norms, but by being opposed to them and constituting an alternative "underground" perspective. The communities offer an alternative understanding of the notion of "health", i.e. such when a body that is usually regarded as a symptom of an illness is not pathologized. In the case of pro-ana, we observe the radical rejection of the recognized way of perceiving eating disorders, which regard anorexia as an illness, which has to be diagnosed and treated.

The girls who write on the blogs gain considerable knowledge of anorexia and the communities they establish may be referred to as expert ones. Furthermore, one should consider to what extent the membership in such communities satisfies many of the needs that young people find important, such as: acceptance, reassurance that there are other people who choose the types of behaviour that are commonly not accepted; the need for belonging, independence and rebellion or the need to build one's identity ${ }^{35}$. It seems that the pro-ana community may guarantee the fulfilment of such needs mainly because of the egosyntonic nature of anorexia, i.e. the fact that rather than being in opposition to the "ego", it becomes its essential element ${ }^{36}$.

The fact that the blogs constitute communities that provide support and the fulfilment of various needs is proven by accurate descriptions of how to "foster" the illness - you can find such fragments in the posts; sometimes they resemble pieces taken out of a guidebook. The girls share their progress on the blogs, they inform each other of the daily calorie intake, of how they manage to avoid eating and how often they vomit etc. A similar community function can be observed in

\footnotetext{
${ }^{34}$ Cf. S.R. Brotsky, D. Giles, Inside the "Pro-ana" Community: A Covert Online Participant Observation, "Eating Disorders: The Journal of Treatment \& Prevention," 2007, No. 15 (2), pp. 93-109.

${ }^{35}$ Cf. D. Giles, Constructing identities in cyberspace: The case of eating disorders, "British Journal of Social Psychology", 2006, No. 45, pp. 463-477.

${ }^{36}$ Cf. M. Starzomska, Egosyntoniczność jako patognomiczny objaw anoreksji, "Psychoterapia," 2008, No. 3 (146), pp. 61-74.
} 
the comments seen under such posts. When looking at such comments, I divided them into three categories - each single comment could belong to all three of them. I have analysed a total of 1011 comments (see Table 2.; I have not provided sample comment, so as not to infringe upon the privacy of the analysed subjects):

1. support comments (encouragement to persist in starvation, praise related to a small calorie intake or effective use of various procedures supporting starvation),

2. advice comments (how to persist in starvation, what methods to use, what to eat and how often etc.),

3. confession comments (sharing one's own experience in starvation, including boasting one's own achievements in this respect).

Table 1. Code categories and their number in the context of examined entries on pro-ana blogs

\begin{tabular}{|c|c|c|}
\hline No. & Code category name (contents of the entries). & $\begin{array}{l}\text { Number of entries in which a giv- } \\
\text { en category occurs and percent- } \\
\text { age of total entries }(\mathrm{N}=561) \text {. }\end{array}$ \\
\hline \multicolumn{3}{|c|}{ Competence according to the model catalogue: efficient and effective access to information. } \\
\hline 1. & $\begin{array}{l}\text { Description and/or a link to press release materials about ano- } \\
\text { rexia. }\end{array}$ & $21 ; 3.7$ percent \\
\hline 2. & $\begin{array}{l}\text { Description and/or a link to scientific materials about anorexia. } \\
\text { (articles, books, magazines, research reports, etc.). }\end{array}$ & 9; 1.6 percent \\
\hline 3. & Description and/or a link to dietary advice found online. & $91 ; 16, .2$ percent \\
\hline 4. & $\begin{array}{l}\text { Description and/or link to online physical exercise tips which are } \\
\text { effective in fighting overweight. }\end{array}$ & 67; 11.9 percent \\
\hline 5. & $\begin{array}{l}\text { Description and/or a link to online advice on how to artificially } \\
\text { induce vomiting. }\end{array}$ & $57 ; 10.2$ percent \\
\hline 6. & $\begin{array}{l}\text { Description and/or a link to online tips on how to artificially in- } \\
\text { duce diarrhoea. }\end{array}$ & $31 ; 5.5$ percent \\
\hline 7. & $\begin{array}{l}\text { Description or/and a link to online tips on how to persevere in } \\
\text { starvation. }\end{array}$ & $132 ; 23.5$ percent \\
\hline 8. & Tips \& tricks containing links to sources. & $51 ; 9.1$ percent \\
\hline \multicolumn{3}{|c|}{ Competence according to the model catalogue: critical evaluation of the information. } \\
\hline 9. & The view that anorexia is not a disease; not treating it as such. & $67 ; 11.9$ percent \\
\hline 10. & $\begin{array}{l}\text { The view that anorexia is a disease, but the claim that you can } \\
\text { "function normally" with it. }\end{array}$ & 28; 5 percent \\
\hline \multicolumn{3}{|c|}{ Competence according to the model catalogue: creation, processing and presentation of information. } \\
\hline 11. & Entries devoted to anorexia. & $37 ; 6.6$ percent \\
\hline 12. & Poems devoted to anorexia. & $43 ; 7.7$ percent \\
\hline 13. & Pet names for the disease. & $184 ; 32.8$ percent \\
\hline 14. & Thinspirations - photographs. & $165 ; 25.3$ percent \\
\hline 15. & Thinspirations - films. & $67 ; 11.9$ percent \\
\hline
\end{tabular}




\begin{tabular}{|c|l|c|}
\hline 16. & Thinspirations - music. & $18 ; 3.2$ percent \\
\hline \multicolumn{2}{|c|}{ Competence according to the model catalogue: safe Internet usage. } \\
\hline 17. & $\begin{array}{l}\text { Personal information: personal data, photos of the face, informa- } \\
\text { tion about the school one is attending. }\end{array}$ & $0 ; 0$ percent \\
\hline 19. & $\begin{array}{l}\text { Information allowing to identify other persons (personal data, } \\
\text { photos, information about the school they attend). }\end{array}$ & $0 ; 0$ percent \\
\hline \multicolumn{2}{|c|}{ Competence according to the model catalogue: participation in communities. } \\
\hline 20. & $\begin{array}{l}\text { References to butterflies, the transformation that the girl under- } \\
\text { goes (from "caterpillar" to "butterfly"). }\end{array}$ & $76 ; 13.5$ percent \\
\hline 21. & References to pro-ana decalogue. & $55 ; 9.8$ percent \\
\hline 22. & References to pro-ana alphabet. & $28 ; 5$ percent \\
\hline 23. & Presentation of different calorie intake limits. & $184 ; 32.8$ percent. \\
\hline 24. & $\begin{array}{l}\text { Sharing your progress (information about daily calorie intake, } \\
\text { successful attempts to avoid eating, frequency of vomiting, etc.) }\end{array}$ & $405 ; 72.2$ percent \\
\hline
\end{tabular}

Source: Own research

Table 2. Content classification of comments to entries where girls share progress in starving themselves

\begin{tabular}{|c|l|c|}
\hline No. & \multicolumn{1}{|c|}{ Comment type. } & $\begin{array}{c}\text { The number of comments of a given type and the percentage of } \\
\text { the total comment under the "progress in starvation" records } \\
(\mathbf{N}=\mathbf{1 0 1 1}) .\end{array}$ \\
\hline 1. & Supporting comments. & $658 ; 65.1$ percent \\
\hline 2. & Comments with advice. & $349 ; 34.5$ percent \\
\hline 3. & Comments with confident info. & $583 ; 57.7$ percent \\
\hline
\end{tabular}

Source: Own research

\section{Discussion and conclusions}

Anorexia nervosa is a western world disease, diagnosed relatively recently. It affects mainly young girls and one of its symptoms is the desire to restrict the intake of food or even starvation. The goal of each person affected with anorexia is to become radically thin. Anorexic people are obsessed with weight loss; they often experience the overwhelming feeling of anger, fear or isolation when they try to gain control over the discord that they believe exists between their mind and body - the former tells them to refrain from eating and the latter tells them something opposite $^{37}$.

${ }^{37}$ K.J. Ward, op. cit. 
Anorexia is in fact much more than just an obsession with physical appearance. For many people it's a way of coping with insecurity ${ }^{38}$. Anorexia results in the elimination of worries and fears related to daily life, in that it allows you to focus on the goal, i.e. slimming. That's why anorexia "seems" attractive - it offers something predictable and "secure", i.e. something that is very difficult to give up ${ }^{39}$. Rigorous procedures are supposed to help you achieve a "perfect" body, but also take control over your life - the girls believe that if they achieve their goal, they will be happy, beautiful and admired. Maybe that's why they personify their affliction and refer to it as "Ana", the "goddess" or a "friend" (as I mentioned before). This "affection" is seen in the case of the pro-ana movement. In this respect, the clinicians' opinion is unambiguous - pro-ana is a threat to health and life, both for the afflicted and for healthy people.

In the event of the afflicted, the key psychopathological factors and symptoms of anorexia are reinforced ${ }^{40}$ - such as asceticism, obsession with self-control, behaviour related to rejecting food (vomiting, pharmacologically induced diarrhoea). Browsing the discussed websites may lead to extending the duration of the illness and increasing the instances of hospitalisation ${ }^{41}$; it may also lead to greater dissatisfaction with one's body and further deterioration of self-esteem. ${ }^{42}$ As shown before, on such websites the afflicted girls find advice and inspiration how to "persist" in their illness.

Healthy people exposed to pro-ana content are more at risk of the illness. This is confirmed by research showing that healthy girls who often visit pro-ana websites have lower self-esteem, low opinion of one's own attractiveness and empowerment, and increasing feeling of being fat as well as the drive for perfection ${ }^{43}$. It is worth noting that even minimum exposure to the pro-ana content may affect the daily calorie intake or developing habits that may bring about the onset of the

38 Ibidem.

39 M.M. Jablow, op cit.

${ }^{40}$ D. Abbate, C. Gramaglia, A. Pierò, S. Fassino, Eating disorders and the internet: cure and curse, "Eating and Weight Disorders - Studies on Anorexia, Bulimia and Obesity," 2006, No. 11 (2), pp. 68-71; R.F. Rodgers, S. Skowron, H. Chabrol, Disordered Eating and Group Membership Among Members of a Pro-anorexic Online Community, "European Eating Disorders Review," 2012, No. 20 (1), pp. 9-12.

${ }^{41}$ J.L. Wilson, R. Peebles, K.K. Hardy, I.F. Litt, Surfing for Thinness: A Pilot Study of Pro-Eating Disorder Web Site Usage in Adolescents With Eating Disorders, "Pediatrics," 2006, No. 118(6), pp. 1635-1643.

${ }^{42}$ K. Harper, S. Sperry, K.J. Thompson, Viewership of pro-eating disorder websites: Association with body image and eating disorder disturbances, "International Journal of Eating Disorders," 2008, 41(1),pp. 92-95.

${ }^{43}$ A. Bardone-Cona, K.M. Cass, Investigating the impact of pro-anorexia websites: a pilot study, "European Eating Disorders Review,",2006, No. 14 (4), pp. 256-262; K. Custers, J. Van den Bulck, Viewership of pro-anorexia websites in seventh, ninth and eleventh graders, "European Eating Disorders Review," 2009, No. 17 (3), pp. 214-219. 
illness ${ }^{44}$. It is so because the described websites are visited mainly by people who have been interested in weight loss before and by those who already have many individual certain risk factors observed in developing the illness ${ }^{45}$ : dissatisfaction with one's own body, experimenting with diets, practising sports, puberty ${ }^{46}$. It is worth mentioning that there is a special term in the pro-ana movement to refer to people who visit or start pro-ana websites, although they are not afflicted themselves. These are the so called wannarexis - healthy girls who want to have anorexia and that's why they search for information on how to lose weight quickly. ${ }^{47}$

Thinspirations, which are supposed to motivate the girls by inducing the mechanism of comparing yourself to others, in fact increase the risk of the disorder ${ }^{48}$. Additionally, pro-ana websites favour the establishment of strong bonds and the girls provide each other with considerable support, which makes it very difficult to "release yourself" from this illness, which is very hard to treat anyway. Being in a community seems to be a symptom of denial, characteristic of anorexia. One could say such communities are a safe shore for those who suffer from anorexia. Sharing information on how to hide the symptoms effectively makes it possible to keep one's health condition secret. On the blogs you can find descriptions of physical afflictions resulting from low food intake. Among those mentioned most often we could list: stomach ache, constipation, dizziness, loss of consciousness, menstruation disorders and afflictions related to provoked vomiting.

The abovementioned negative impact of pro-ana influenced many associations that combat eating disorders to try and counteract this phenomenon. Such actions most often involve writing petitions to the governments of individual countries, asking them to introduce relevant legislation and make the websites that promote anorexia illegal ${ }^{49}$. Such petitions are unsuccessful, though - so far, the law is that

44 S. Jett, D.J. LaPorte, J. Wanchisn, Impact of exposure to pro-eating disorder websites on eating behaviour in college women, "European Eating Disorders Review," 2010, No. 18 (5), pp. 410-416.

${ }^{45}$ Por. I. Startek, Motyle w sieci. Krótka charakterystyka ruchu pro-Ana, "Curr Probl Psychitry," 2011, No. 12 (3), pp. 322-329.

${ }^{46}$ B. Józefik, Epidemiologia zaburzeń odżywiania, [in:] Anoreksja i bulimia psychiczna. Rozumienie i leczenie zabużeń odżywiania, B. Józefik (red.), Kraków 1999, Wydawnictwo Uniwersytetu Jagiellońskiego, pp. 22-29.

47 Cf. I. Startek, op. cit.

${ }^{48}$ Cf. R. Maksymiuk, A. Jasielska, Rola mass mediów i reklamy $w$ powstawaniu anoreksji $i$ bulimii $w$ okresie adolescencji (The role of mass media and advertising in the formation of anorexia and bulimia during adolescence), [in:] Wybrane zagadnienia z psychologii klinicznej i osobowości. Psychologia kliniczna nastolatka (Selected Issues from Clinical Psychology and Personality. Clinical Psychology of Adolescents), L. Szewczyk, E. Talik (eds), Lublin 2009, TN KUL, pp. 183-208.

${ }^{49}$ M. Stochel, M. Janas-Kozik, Przyjaciółki wirtualnej Any - zjawisko proanoreksji w sieci internetowej (Friends of virtual Ana: The phenomenon of pro-anorexia on the Internet), "Psychiatria Polska," 2010, No. 44 (5), p. 697. 
internet companies are not responsible for the content uploaded by the individual users $^{50}$. Although the major companies (Google, YouTube, Facebook etc.) more and more often perceive that pro-ana websites, profiles and groups have a negative impact on the brand image, it is very difficult to counteract them. Individual profiles in social media can be blocked, but various blogs and websites still flourish. Besides, even if they are closed, they are later revived under a different, often hidden name (without referring to pro-ana ${ }^{51}$ ).

As we can see, pro-ana blogs do not promote the development and growth of young girls (social or cultural) - quite the opposite, they have a very bad influence on them. Still, pro-ana bloggers may be recognized as incredibly competent internet users when their activity is analysed from the perspective of the model catalogue, as presented by me. Although there are catalogues - as I mentioned in the introduction - whose preambles include the information that being competent involves behaviour that is beneficial to some person and their environment, providing this information is not a common practice. It is much more common to just list individual catalogue items. The example of pro-ana blogs proves that the researchers who create the catalogues simply fetishize theoretical categories, which is a great methodological negligence.

This type of behaviour was described by Mirosław Filiciak ${ }^{52}$ in the context of media studies, where he showed that the representatives of film or culture studies, in their deliberations concerning media transformations, keep using the so called "zombie terms" - notions that mean nothing and function only in books or magazines. One of such notions was Web 2.0, referring to the websites based on the voluntary, grassroots amateur work. It's more and more difficult to find real-life references for zombie terms, whereby using them follows from the specific position of the media researchers and their singular motivation. The scientists seem to be creating the area of their own research in that they construct certain notions that are dead and non-functional in real life, yet operable in their scientific work. And they do it, because they find it convenient. To put it simply and generally, we could say that the scientists do it, so that they have something to study and so that their theories sound interesting and seem to have considerable cognitive value.

\footnotetext{
${ }^{50}$ Cf. W. Orliński, "Internet. Czas się bać” ("Internet. Time to be afraid”), Agora S.A., Warszawa 2013.

${ }^{51} \mathrm{Cf}$. A. Giedrojć, Forum internetowe „Anoreksja”. Reklama, wołanie o pomoc czy poradnictwo (“Anorexia" Internet Forum. Advertising, call for help or counselling), [in:] Edukacja, wychowanie, poradnictwo w kulturze popularnej (Education, Upbringing, Guidance in Popular Culture), M. Kondracka, A. Łysak (eds), Wrocław 2009, Biblioteka Uniwersytecka we Wrocławiu, pp. 97-104.

${ }_{52}$ M. Filiciak, "Media. Wersja Beta" ("Media. Beta Version"), Wydawnictwo Naukowe Katedra, Gdańsk 2013.
} 
It is similar in the case of information literacy, that's why it's incredibly important to make the relevant deliberations context-sensitive, as proposed by the promoters of the abovementioned position. It's not about the complete elimination of all the catalogues, but about enriching and supplementing them with the analysis of the everyday life of young people. Maybe it's worth "leaving the desk" and commence "field analysis" to illustrate and picture the various ways young people use the internet, including those apparently consistent with the catalogues.

My purpose is, of course, not to show that children and adolescents should not be educated as regards information literacy related to using the internet. Neither do I want to show that you can't construct catalogues like generic researchers do. On the contrary, competences should be somehow ordered in the education of young people. However, we need to distance ourselves from the catalogues and see that they are theoretical constructs, which do not fully reflect the social reality.

A proposed solution is to distinguish something we could describe as negative competent use, i.e. competent use of the network, which is not beneficial to children or adolescents. This type of action should be taken mainly by the representatives of the generic approach. When creating catalogues, they should simultaneously point to negative competent use (shown from the perspective of an individual catalogue). The identification of such use could be performed on the basis of the abovementioned "field analysis", which is particularly important in the times when the use of the internet and the computer is becoming more and more flexible and customized. What could also be helpful is the desk research - this is definitely a less expensive option, which could be an advantage for people who do not have sufficient resources.

The procedure of distinguishing negative competent uses allows us to see that young people do not necessarily have to use the knowledge they gain only in the way the researchers and educators imagine. However, it's not enough to instil further skills included in the catalogues - it's also important to make people sensitive to the "bad" use of such skills. The lack of such sensitivity may breed adverse consequences both at the planning stage and later, when the education process is being implemented.

When writing about the desired ways of educating young people, the researchers may "isolate" themselves in a sort of self-satisfied bubble and be content in thinking that the use of the proposed solutions will always produce "good" results, i.e. the education and growth of children and adolescents. Unfortunately, this will not be so when theoretical assumptions are "translated" into "real" life. Drawing on the generically created catalogues in the education of young people may make 
us insensitive to the abovementioned negative competent use. Noticing such use as early as at the stage of creating theoretical recommendations would be helpful in eliminating this type of use later on.

The example of pro-ana blogs discussed in this article has shown that the skills indicated as necessary to master may be used by young people in a wrong way and as such may lead to tragic results. The educational process needs to be planned and implemented in connection with the everyday experience of young people. Researchers need to learn about various shades of their culture, their problems and social practice. It should be remembered also when creating the catalogues of information literacy related to the internet use.

\section{References}

AASL, Standards for the 21st-Century Learner, 2007, http://www.ala.org/aasl/standards-guidelines/ learning-standards (accessed on: 12.03.2016).

AASL, AECT, Information Literacy Standards for Student Learning: Standards and Indicators, 1998, http://www.ilipg.org/sites/ilipg.org/files/bo/InformationLiteracyStandards_final.pdf (accessed on: 12.03.2016).

Abbate D., Gramaglia C., Pierò A., Fassino S., Eating disorders and the internet: cure and curse, "Eating and Weight Disorders - Studies on Anorexia, Bulimia and Obesity", 2006, No. 11 (2), pp. 68-71.

ANZIIL, Australian and New Zealand Information Literacy Framework: principles, standards and practice, 2004, http://www.caul.edu.au/caul-programs/information-literacy/publications (accessed on: 12.03.2016).

Bardone-Cona A., Cass K.M., Investigating the impact of pro-anorexia websites: a pilot study, "European Eating Disorders Review," 2006, No. 14 (4), pp. 256-262.

Barczak M., Krótka charakterystyka dzienników internetowych dziewcząt $z$ anoreksją (Internet diaries by girls with anorexia: A brief description), [in:] Opętanie (nie)jedzeniem [(Non)-eating Obsession], B. Ziółkowska (red.), Warszawa 2009, Scholar, pp. 155-158.

Berry D.M., Internet research: privacy, ethics and alienation: an open source approach, "Internet Research," 2004, No. 4 (14), pp. 323-332.

Blasius J., Brandt M., Representativeness in Online Surveys through Stratified Samples, "Bulletin de Méthodologie Sociologique", 2010, No. 107, pp. 5-21.

Brotsky S.R., Giles D., Inside the "Pro-ana" Community: A Covert Online Participant Observation, “Eating Disorders: The Journal of Treatment \& Prevention,” 2007, No. 15 (2), pp. 93-109.

Brown J.S., Duguid P., Knowledge and organization: A social practice perspective, "Organization Science", 2001, No. 12 (2), pp. 198-213.

Csipke E., Horne O., Pro-eating disorder websites: Users' opinions, “European Eating Disorders Review," 2007, No. (3), pp. 196-206.

Custers K., Van den Bulck J., Viewership of pro-anorexia websites in seventh, ninth and eleventh graders, "European Eating Disorders Review," 2009, No. 17 (3), pp. 214-219. 
Dias K., The Ana Sanctuary: Women's Pro-Anorexia Narratives in Cyberspace, "Journal of International Women's Studies," 2013, No. 4 (2), pp. 31-45.

Dyke S., Utilising a blended ethnographic approach to explore the online and offline lives of pro-ana community members, "Ethnography and Education," 2013, No. 8(2), pp. 146-161.

Edwards S., Bruce C., The assignment that triggered change: Assessment and the relational model for generic capabilities, "Assessment and Evaluation in Higher Education," 2004, No. 29 (2), pp. 141-157.

Eisenberg M., Berkowitz R., "Information problem-solving: The Big Six approach to library \& information skills instruction," Ablex, Norwood 1990.

Endres B., A critical read on critical literacy: From critique to dialogue as an ideal for literacy education, "Educational Theory", 2001, No. 51(4), pp. 401-413.

Ferreday D., Unspeakable Bodies. Erasure, Embodiment and the Pro-Ana Community, "International Journal of Cultural Studies," 2003, No. 6 (3), pp. 277-295.

Filiciak M., “Media. Wersja Beta," Wydawnictwo Naukowe Katedra, Gdańsk 2013.

Fleming-May R., Miller L.E., "I'm scared to look. But I'm dying to know": Information seeking and sharing on Pro-Ana weblogs, "Proceedings of the American Society for Information Science and Technology," 2010, No. 47 (1), pp. 1-9.

Fox N.J., Ward K.J., O'Rourke A.J., 'Expert Patients', Pharmaceuticals and the Medical Model of Disease: The Case of Weight Loss Drugs and the Internet, "Social Science and Medicine," 2005, No. 60 (6), pp. 1299-1309.

Fox N.J., Ward K.J., O'Rourke A.J., Pro-Anorexia, Weight Loss Drugs and the Internet: An AntiRecovery Explanatory Model of Anorexia, "Sociology of Health and Illness", 2005, No. 27 (7), pp. 944-971.

Fricker R.D., Schonlau M., Advantages and Disadvantages of Internet Research Surveys: Evidence from the Literature, "Field Methods," 2002, No. 14 (4), pp. 347-367.

Giedrojć A., Forum internetowe „Anoreksja”. Reklama, wołanie o pomoc czy Poradnictwo "Anorexia" Internet Forum. Advertising, call for help or counselling, [in:] Edukacja, wychowanie, poradnictwo w kulturze popularnej (Education, Upbringing, Guidance in Popular Culture), M. Kondracka, A. Łysak (eds), Wrocław 2009, Biblioteka Uniwersytecka we Wrocławiu, pp. 97-104.

Giles D., Constructing identities in cyberspace: The case of eating disorders, "British Journal of Social Psychology," 2006, No. 45, pp. 463-477.

Harper K., Sperry S., Thompson K.J., Viewership of pro-eating disorder websites: Association with body image and eating disorder disturbances, "International Journal of Eating Disorders," 2008, 41(1), pp. 92-95.

Harris P., Communities as necessity in information literacy development: Challenging the standards, "Journal of Academic Librarianship", 2008, No. 34, pp. 248-255.

IFLA, Beacons of the Information Society: The Alexandria Proclamation on Information Literacy and Lifelong Learning, 2005, http://www.ifla.org/publications/beacons-of-the-information-society-the-alexandria-proclamation-on-information-literacy (accessed on: 12.03.2016).

IFLA, The Moscow Declaration on Media and Information Literacy, 2012, http://www.ifla.org/publications/moscow-declaration-on-media-and-information-literacy (accessed on: 12.03.2016).

Jablow M.M., "Anoreksja, bulimia, otyłość. Przewodnik dla rodziców” (“Anorexia, bulimia, obesity. Guide for parents"), Gdańskie Wydawnictwo Pedagogiczne, Gdańsk 2000.

Jett S., LaPorte D.J., Wanchisn J., Impact of exposure to pro-eating disorder websites on eating behaviour in college women, "European Eating Disorders Review," 2010, No. 18 (5), pp. 410-416. 
Józefik B., Epidemiologia zaburzeń odżywiania (Epidemiology of eating disorders), [in:] Anoreksja i bulimia psychiczna. Rozumienie i leczenie zabużeń odżywiania (Anorexia and Mental Bulimia. Understanding and Treating Eating Disorders), B. Józefik (ed.), Kraków 1999, Wydawnictwo Uniwersytetu Jagiellońskiego, pp. 22-29.

Klichowski M., Pro-ana - internetowa sekta nastolatek (Pro-ana - teenagers' online sect for), [in:] Świat Digital Natives. Młodzież w poszukiwaniu siebie i innych (Digital Natives World. Young People in Search of Themselves and Others), H. Krauze-Sikroska, M. Klichowski (eds), Poznań 2013, Wydawnictwo Naukowe UAM, pp. 157-172.

King S.A., Researching Internet Communities: Proposed Ethical Guidelines for the Reporting of Results, “The Information Society," 1996, No. 12, pp. 119-127.

Kozinets R.V., "Netnography: Doing Ethnographic Research Online," SAGE Publications, London-Thousand Oaks-New Delhi 2010.

Krantz J.H., Dalal R., Validity of Web-Based Psychological Research, [in:] Psychological Experiments on the Internet, M.H. Birnbaum (ed.), New York 2000, Academic Press, pp. 35-60.

Lipponen L., Information literacy as situated and distributed activity, [in:] Practising Information Literacy: Bringing Theories of Learning, Practice and Information Literacy Together, A. Lloyd, S. Talja (eds), Wagga Wagga 2010, Centre for Information Studies, pp. 51-64.

Livingstone S., Children's use of the internet: Reflections on the emerging research Agenda, "New Media \& Society," 2003, No. 5(2), pp. 147-166.

Livingstone S., "Children and the Internet," Polity Press, Cambridge-Malden 2009.

Lloyd A., Lessons from the workplace: Understanding information literacy as practice, [in:] Practising Information Literacy: Bringing Theories of Learning, Practice and Information Literacy Together, A. Lloyd, S. Talja (eds), Wagga Wagga 2010, Centre for Information Studies, pp. 29-50.

Lupton M., "The learning connection: Information literacy and the student experience," Auslib Press, Adelaide 2004.

Lupton M., Bruce C., Windows on information literacy worlds: Generic, situated and transformative perspectives, [in:] Practising Information Literacy: Bringing Theories of Learning, Practice and Information Literacy Together, A. Lloyd, S. Talja (eds), Wagga Wagga 2010, Centre for Information Studies, pp. 3-28.

Maksymiuk R., Jasielska A., Rola mass mediów i reklamy w powstawaniu anoreksji i bulimii w okresie adolescencji (The role of mass media and advertising in the formation of anorexia and bulimia during adolescence), [in:] Wybrane zagadnienia z psychologii klinicznej i osobowości. Psychologia kliniczna nastolatka (Selected Issues from Clinical Psychology and Personality. Clinical Psychology of Adolescents), L. Szewczyk i E. Talik (eds.), Lublin 2009, TN KUL, pp. 183-208.

Orliński W., "Internet. Czas się bać" ("Internet. Time to be afraid"), Agora S.A., Warszawa 2013.

Peden B.F., Flashinski D.P., Virtual Research Ethics: A Content Analysis of Surveys and Experiments Online, [in:] Readings in Virtual Research Ethics. Issues and Controversies, E.A. Buchanan (ed.), Hershey-London-Melbourne-Singapore 2004, INFOSCI, pp. 1-26.

Purdue J., Stories, not information: Transforming information literacy, "Portal: Libraries and the Academy," 2003, No. 3(4), pp. 653-662.

Reips U.D., Standards for Internet-Based Experimenting, "Experimental Psychology," 2002, No. 49 (4), pp. 243-256.

Rettberg J.W., "Blogging," Polity Press, Cambridge-Malden 2013.

Rodgers R.F., Skowron S., Chabrol H., Disordered Eating and Group Membership Among Members of a Pro-anorexic Online Community, "European Eating Disorders Review," 2012, No. 20 (1), pp. 9-12. 
Rozkosz E.A., Siuda P., Stunża G.D., Dąbrowska A.J., Klimowicz M., Kulczycki E., Muszyński D., Piotrowska R., Sieńko M., Stachura, K., Information and Media Literacy of Polish Children According to the Results of "Children of the Net" and "Children of the Net 2.0" Studies, [in:] Information Literacy: Lifelong Learning and Digital Citizenship in the 21st Century, S. Kurbanoğlu, S. Špiranec, D. Mizrachi, R. Catts (eds), Cham 2014, Springer, pp. 263-273.

Siuda P. Społeczności wirtualne. O wspólnotowości w społeczeństwie sieciowym (Virtual Communities. On Community in a Network Society), [in:] Oblicza Internetu, Internet w przestrzeni komunikacyjnej XXI wieku (Faces of the Internet. Internet in the Communication Space of the 21st Century), M. Sokołowski (ed.), Elbląg 2006, Wydawnictwo PWSZ, pp. 179-186.

Siuda P., Stunża G.D. (red.), "Dzieci Sieci - kompetencje komunikacyjne najmłodszych: Raport z badan'" ("Children of the Network - Communication Competences of the Youngest Children: Research Report”), Instytut Kultury Miejskiej, Gdańsk 2012.

Siuda P., Stunża G.D., Dąbrowska A.J., Klimowicz M., Kulczycki E., Piotrowska R., Rozkosz E., Sieńko M., Stachura K. "Dzieci Sieci 2.0. Kompetencje komunikacyjne młodych" "“Children of the Network 2.0 Communication Skills of Young People”), Instytut Kultury Miejskiej, Gdańsk 2013.

Startek I., Motyle w sieci. Krótka charakterystyka ruchu pro-Ana (Butterflies in the net. A brief characteristics of pro-anna movement), "Curr Probl Psychitry," 2011, No. 12 (3), pp. 322-329.

Starzomska M., Egosyntoniczność jako patognomiczny objaw anoreksji (Egosyntonics as a pathognomic manifestation of anorexia), "Psychoterapia," 2008, No. 3 (146), pp. 61-74.

Stochel M., Janas-Kozik M., Przyjaciółki wirtualnej Any - zjawisko proanoreksji w sieci internetowej (Friends of virtual Ana: The phenomenon of pro-anorexia on the Internet), "Psychiatria Polska", 2010, $\mathrm{nr} 44$ (5), s. 693-702.

Talja S., Lloyd A., Integrating theories of learning, literacies and information practices, [in:] Practising Information Literacy: Bringing Theories of Learning, Practice and Information Literacy Together, A. Lloyd, S. Talja (eds), Wagga Wagga 2010, Centre for Information Studies, pp. VIII-XX.

Tuominen K., Savolainen R., Talja S., Information literacy as sociotechnical practice, "Library Quarterly," 2005, No. 75, pp. 329-345.

Yeshua-Katz D., Martins N., Communicating Stigma: The Pro-Ana Paradox, "Health Communication," 2013, No. 28 (5), pp. 499-508.

Ward K.J., 'I Love You to the Bones': Constructing the Anorexic Body in 'Pro-Ana' Message Boards, "Sociological Research Online," 2007, No. 12 (2), http://www.socresonline.org.uk/12/2/ward.htm (accessed on: 12.03.2016).

Wenger E., "Communities of Practice: Learning, Meaning, and Identity (Learning in Doing: Social, Cognitive and Computational Perspectives)," Cambridge University Press, Cambridge 2000.

Wilson J.L., Peebles R. Hardy K.K., Litt I.F., Surfing for Thinness: A Pilot Study of Pro-Eating Disorder Web Site Usage in Adolescents With Eating Disorders, "Pediatrics," 2006, No. 118(6), pp. 16351643. 